\title{
Intake and digestibility of lamb fed diets containing banana crop residues
}

\author{
Tânia Dayana do Carmo(1), Paula Miranda Barbosa(1), Luciana Castro Geraseev(1), \\ Diego Santana Costa ${ }^{(1)}$, Geziana Moreira Seles ${ }^{(1)}$ and Eduardo Robson Duarte ${ }^{(1)}$
}

\begin{abstract}
(1)Universidade Federal de Minas Gerais, Instituto de Ciências Agrárias, Avenida Universitária, no 1.000, Bairro Universitário, CEP 39404-547 Montes Claros, MG, Brazil. E-mail: taniad.carmo@gmail.com, paulamiranda@zootecnista.com.br, Igeraseev@gmail.com, diegosanct@yahoo.com.br, geziana23@hotmail.com, duartevet@hotmail.com
\end{abstract}

\begin{abstract}
The objective of this work was to evaluate the effects of the inclusion of banana leaf or pseudostem hay in complete diets on the intake, nutrient digestibility, and ruminal short-chain fatty acid production by lambs. A total of 30 Santa Inês x Dorper lambs were allocated to five treatments: $400 \mathrm{~g} \mathrm{~kg}^{-1}$ Cynodon spp. hay; $200 \mathrm{~g} \mathrm{~kg}^{-1}$ banana leaf hay $+200 \mathrm{~g} \mathrm{~kg}^{-1}$ Cynodon spp. hay; $400 \mathrm{~g} \mathrm{~kg}^{-1}$ banana leaf hay; and $200 \mathrm{~g} \mathrm{~kg}^{-1}$ banana pseudostem hay $+200 \mathrm{~g} \mathrm{~kg}^{-1}$ Cynodon spp. hay and $400 \mathrm{~g} \mathrm{~kg}^{-1}$ banana pseudostem hay. The inclusion of banana crop residues had no effect on dry matter intake, organic matter, crude protein, neutral detergent fiber (NDF), acid detergent fiber, non-fiber carbohydrates, and total carbohydrates, which presented averages of $1,086.8,1,000.1,182.7,374.3,194.7,390.2$, and $771.6 \mathrm{~g}$ per day, respectively. There was a reduction in NDF digestibility with the inclusion of $400 \mathrm{~g} \mathrm{~kg}^{-1}$ leaf hay, but no differences were observed in the other treatments. The addition of both banana leaf and pseudostem hay can replace Cynodon spp. hay without affecting intake, nutrient digestibility, and ruminal concentration of short-chain fatty acids.
\end{abstract}

Index terms: Musa, by-product, hay, nutritional value, volatile fatty acids.

\section{Consumo e digestibilidade em ovinos alimentados com dietas contendo resíduos da bananicultura}

\begin{abstract}
Resumo - O objetivo deste trabalho foi avaliar os efeitos da inclusão de feno de folha ou pseudocaule de banana em dietas completas sobre a ingestão, a digestibilidade de nutrientes e a produção ruminal de ácidos graxos de cadeia curta em cordeiros. Foram utilizados 30 cordeiros Santa Inês x Dorper, alocados em cinco tratamentos: $400 \mathrm{~g} \mathrm{~kg}^{-1}$ de feno de Cynodon spp.; $200 \mathrm{~g} \mathrm{~kg}^{-1}$ de feno de folha de bananeira $+200 \mathrm{~g} \mathrm{~kg}^{-1} \mathrm{de}$ feno de Cynodon spp.; $400 \mathrm{~g} \mathrm{~kg}^{-1}$ de feno de folha de bananeira; e $200 \mathrm{~g} \mathrm{~kg}^{-1}$ de feno de pseudocaule de banana $+200 \mathrm{~g} \mathrm{~kg}^{-1}$ de feno de Cynodon spp. e $400 \mathrm{~g} \mathrm{~kg}^{-1}$ de feno de pseudocaule de banana. A inclusão de resíduos culturais de banana não teve efeito sobre consumo de matéria seca, matéria orgânica, proteína bruta, fibra em detergente neutro (FDN), fibra em detergente ácido, carboidratos não fibrosos e carboidratos totais, cujas médias foram de 1.086,8,1.000,1, 182,7, 374,3, 194,7, 390,2 e 771,6 g por dia, respectivamente. Houve redução na digestibilidade da FDN com a inclusão de $400 \mathrm{~g} \mathrm{~kg}^{-1}$ de feno de folhas, mas não foram observadas diferenças nos outros tratamentos. A adição de feno de folha e de pseudocaule de banana pode substituir o feno de Cynodon spp. sem alterar a ingestão, a digestibilidade de nutrientes e a concentração ruminal de ácidos graxos de cadeia curta.
\end{abstract}

Termos para indexação: Musa, coproduto, feno, valor nutricional, ácidos graxos voláteis.

\section{Introduction}

Finishing lambs in confinement is a viable alternative to obtain higher-quality carcasses (Raineri et al., 2014). However, the production costs of confined animals are considered high due to factors as the great volume of grains and cereals used in the concentrate diets, especially in semiarid regions (Barros et al., 2015). Most of the time, the low amount of forage during the dry period and the need to invest in irrigated systems for forage cultivation and/or to import supplies make the adoption of this system unfeasible in these areas (Barreto et al., 2014).

In this context, agroindustry residues are a feed option to be considered. The inclusion of these materials in the diets of ruminants allows mutual benefits to both agro-industries and livestock (Braga Sobrinho, 2014). One of the main residues with 
potential for use in ruminant nutrition are those from the banana (Musa spp.) crop (Geraseev et al., 2013; Oliveira et al., 2014). However, although the leaves and pseudostem of banana trees are highly digestible by ruminants, their intake is limited when provided in nature or ensiled as an exclusive source of food. This is due to the low dry matter content of both leaves and pseudostem, the reduced concentration of crude protein in the pseudostem (Oliveira et al., 2014), and the presence of secondary metabolites such as condensed tannins, particularly in the leaves (Hembade \& Niras, 2014). The use of these materials as hay, however, in combination with other feedstuff, may minimize these limitations.

Few studies have been carried out using banana leaves and pseudostem as hay in ruminant feeding; therefore, information regarding the intake, digestibility, and effects of this inclusion on ruminal fermentation is scarce. Geraseev et al. (2013) studied the addition of 200 or $400 \mathrm{~g} \mathrm{~kg}^{-1}$ leaf or pseudostem hay in the diet of confined lambs and obtained satisfactory results for dry matter intake and weight gain, but did not assess the effect of the diet on fermentation products.

The objective of this work was to evaluate the inclusion of banana leaf or pseudostem hay in complete diets on the intake, nutrient digestibility, and ruminal production of short-chain fatty acids by lambs.

\section{Materials and Methods}

The procedures used in this research were approved by the ethics committee in animal experimentation of Universidade Federal de Minas Gerais under protocol number 164/11.

The study consisted of 30 Santa Inês x Dorper cross-breed lambs, male and castrated, aged between four and seven months. The experimental design was randomized complete blocks, consisting of three blocks, five treatments, and six replicates. The blocks were defined according to the initial body weight of the animals: mean live weight of $42.39 \pm 4.8 \mathrm{~kg}$ for the first block, of $37.92 \pm 4.25 \mathrm{~kg}$ for the second, and of $24.33 \pm 3.4 \mathrm{~kg}$ for the third. The experiment was carried out between June and August 2013, during 60 days, divided into three 20-day periods (with 15 days for adaptation and 5 days for data collection).

The experimental diets were formulated according to the recommendations of Nutrient... (2007) in order to meet the requirements of lambs with a mean weight of $35 \mathrm{~kg}$ and estimated gain of $200 \mathrm{~g}$ per day, using a ratio of 0.60 concentrate and 0.40 forage (Table 1).

The following treatments were evaluated: 400 $\mathrm{g} \mathrm{kg}^{-1}$ Cynodon spp. hay; $200 \mathrm{~g} \mathrm{~kg}^{-1}$ banana leaf hay $+200 \mathrm{~g} \mathrm{~kg}^{-1}$ Cynodon spp. hay; $400 \mathrm{~g} \mathrm{~kg}^{-1}$ banana leaf hay; $200 \mathrm{~g} \mathrm{~kg}^{-1}$ banana pseudostem hay $+200 \mathrm{~g} \mathrm{~kg}^{-1}$ Cynodon spp. hay; and $400 \mathrm{~g} \mathrm{~kg}^{-1}$ banana pseudostem hay (Table 2).

The leaves and pseudostem from the banana trees were collected immediately after fruit harvesting. The pseudostem was cut into $50-\mathrm{cm}$ blocks, followed by the removal of the sheath in order to facilitate material processing in a disintegrator regulated to cut into 2 to 3-cm blocks. After being chopped, the leaves and pseudostem were separately homogenized and dried under the sun until reaching 10-12\% humidity, which was achieved after 72-120 hours. The material was later conditioned in polyethylene bags and stored.

Animals were placed in individual cages equipped with water and food dispensers and a feces collector. Diets were provided twice a day, at 7:00 a.m. and 4:00 p.m. in an ad libitum system, with $100 \mathrm{~g} \mathrm{~kg}^{-1}$ of the amount offered in natural matter as leftovers. Intake was adjusted every morning, before the first meal, using the weights of food and leftovers. During the five days for data collection, samples from the diet, leftovers, and feces (total collection method) were collected daily; for feces, this was done in the morning and afternoon prior to animal feeding. All samples were stored at $-20^{\circ} \mathrm{C}$. At the completion of the experiment, samples per animal and per period of 24 hours - five samples per animal for each collecting period - were analyzed separately.

Samples from the offered food, leftovers, and feces were pre-dried in an air-forced oven at $55^{\circ} \mathrm{C}$ and grinded in a Willey grinder with 1-mm diameter sieves. All samples were subjected to the analyses of dry matter (DM), crude protein (CP), ether extract (EE), neutral detergent fiber (NDF), acid detergent fiber (ADF), neutral detergent insoluble nitrogen (NDIN), acid detergent insoluble nitrogen (ADIN), and ash content according to Instituto Nacional de Ciência e Tecnologia de Ciência Animal (Detmann et al., 2012). Lignin content was obtained by acid hydrolysis as previously described by Van Soest (1965).

In vitro dry matter digestibility (IVDMD) of banana leaf and pseudostem and of Cynodon spp. hay was 
carried out according to the methodology of Tilley \& Terry (1963) and Holden (1999), modified for use of the TE-150 in vitro incubator (Tecnal Equipamentos Científicos, Piracicaba, SP, Brazil). The ruminal liquid was collected from two male castrated lambs using a fixed fistula in the rumen. Fistulated animals were fed a diet containing $300 \mathrm{~g} \mathrm{~kg}^{-1}$ commercial concentrate and $700 \mathrm{~g} \mathrm{~kg}^{-1}$ forage based on Cynodon spp. hay.

The content of condensed tannins was determined in 15-g samples of banana leaf, banana pseudostem, and Cynodon spp. hay by undergoing catalyzed solvolysis using $\mathrm{n}-\mathrm{BuOH} / \mathrm{HCl} 37 \%$ (95:5), according to Hiermann et al. (1986). The absorbance of the solution was read at $540 \mathrm{~nm}$, with values expressed as cyanidin chloride. The results are the means of three determinations.

On the final experimental day, using an oral gavage adapted to a vacuum pump, $100 \mathrm{~mL}$ rumen liquid were collected after animals were fasted for 12 hours (Tabeleão et al., 2008). The $\mathrm{pH}$ of the rumen fluid was measured immediately after collection using a digital potentiometer; an average value of $7.0 \pm 0.15$ was obtained.

Then, $60 \mathrm{~mL}$ rumen liquid were placed in plastic flasks and stored at $-10^{\circ} \mathrm{C}$ for the analysis of shortchain fatty acids (SCFA). Samples of rumen liquid were thawed to room temperature, centrifuged at $13,000 \mathrm{rpm}$ for $15 \mathrm{~min}$ at $10^{\circ} \mathrm{C}$, and stored in Eppendorf tubes. In order to determine the concentration of SCFA, samples were stored at a ratio of $500 \mu \mathrm{L}$ rumen liquid and 500 $\mu \mathrm{L}$ formic acid at $88 \%$ (Nocek et al., 1987).

The separation and quantification of SCFA were performed by the methodology adapted from Nocek et al. (1987), using the GC-2014 gas chromatograph (Shimadzu do Brasil, Barueri, SP, Brazil) coupled to a flame ionization detector and HP INNOWax column (30 m length $\times 0.32 \mathrm{~mm}$ internal diameter) (Agilent, Santa Clara, CA, USA). The following settings were adopted for the instrument: injector temperature of

Table 1. Nutritional composition of the experimental diets ${ }^{(1)}$.

\begin{tabular}{|c|c|c|c|c|c|}
\hline $\begin{array}{l}\text { Ingredient } \\
\left(\mathrm{g} \mathrm{kg}^{-1}\right)\end{array}$ & $\begin{array}{c}400 \mathrm{~g} \mathrm{~kg}^{-1} \\
\text { Cynodon spp. hay }\end{array}$ & $\begin{array}{c}400 \mathrm{~g} \mathrm{~kg}^{-1} \\
\text { banana leaf hay }\end{array}$ & $\begin{array}{c}200 \mathrm{~g} \mathrm{~kg}^{-1} \\
\text { banana leaf hay }\end{array}$ & $\begin{array}{c}400 \mathrm{~g} \mathrm{~kg}^{-1} \\
\text { banana pseudostem hay }\end{array}$ & $\begin{array}{c}200 \mathrm{~g} \mathrm{~kg}^{-1} \\
\text { banana pseudostem hay }\end{array}$ \\
\hline Cynodon spp. & 400.0 & - & 200.0 & - & 200.0 \\
\hline Banana leaf hay & - & 400.0 & 200.0 & - & - \\
\hline Pseudostem hay & - & - & - & 400.0 & 200.0 \\
\hline Corn grain & 452.0 & 400.0 & 461.4 & 382.7 & 417.5 \\
\hline Soybean meal & 51.6 & 44.1 & 40.5 & 118.3 & 84.9 \\
\hline Cotton meal & 80.0 & 80.0 & 80.0 & 80.0 & 80.0 \\
\hline Limestone & 5.1 & 0.3 & 2.8 & 0.4 & 2.9 \\
\hline Dicalcium phosphate & - & 8.3 & 4.0 & 7.3 & 3.4 \\
\hline Common salt & 2.8 & 2.8 & 2.8 & 2.8 & 2.8 \\
\hline Urea & 5.0 & 5.0 & 5.0 & 5.0 & 5.0 \\
\hline Vitamin-mineral premix ${ }^{(2)}$ & 3.5 & 3.5 & 3.5 & 3.5 & 3.5 \\
\hline \multicolumn{6}{|l|}{ Nutrients $\left(\mathrm{g} \mathrm{kg}^{-1} \mathrm{DM}\right)$} \\
\hline $\mathrm{DM}\left(\mathrm{g} \mathrm{kg}^{-1} \mathrm{NM}\right)$ & 884.9 & 904.9 & 895.1 & 893.9 & 887.4 \\
\hline MM & 69.1 & 81.9 & 69.9 & 84.1 & 76.5 \\
\hline $\mathrm{CP}$ & 160.0 & 160.0 & 160.0 & 160.0 & 160.0 \\
\hline NFC & 341.9 & 367.7 & 357.5 & 410.9 & 377.9 \\
\hline $\mathrm{NDF}$ & 381.8 & 339.5 & 360.5 & 304.0 & 345.2 \\
\hline $\mathrm{ADF}$ & 180.6 & 191.7 & 183.1 & 167.9 & 172.8 \\
\hline $\mathrm{EE}$ & 47.2 & 52.1 & 50.9 & 33.0 & 40.4 \\
\hline NDIN & 21.0 & 13.0 & 17.1 & 11.4 & 13.6 \\
\hline ADIN & 7.1 & 6.8 & 5.8 & 6.6 & 7.8 \\
\hline Lignin & 18.8 & 34.9 & 30 & 18.4 & 20.8 \\
\hline
\end{tabular}

${ }^{(1)} \mathrm{DM}$, dry matter; NM, natural matter, MM, mineral matter; CP, crude protein; NFC, non-fibrous carbohydrate; NDF, neutral detergent fiber; ADF, acid detergent fiber; EE, ether extract, NDIN, neutral detergent insoluble nitrogen; and ADIN, acid detergent insoluble nitrogen. ${ }^{(2)}$ Composition: $150 \mathrm{~g}$ calcium (max.), $130 \mathrm{~g}$ calcium (min.), $65 \mathrm{~g}$ phosphorus (min.), $130 \mathrm{~g}$ sodium (min.), $650 \mathrm{mg}$ fluorine (max.), $12 \mathrm{~g}$ sulfur (min.), $10 \mathrm{~g}$ magnesium (min.), $1,000 \mathrm{mg}$ iron (min.), 3,000 mg manganese (min.), $80 \mathrm{mg}$ cobalt (min.), 5,000 $\mathrm{mg}$ zinc (min.), $60 \mathrm{mg}$ iodine (min.), $10 \mathrm{mg}$ selenium (min), 50,000 IU vitamin A (min.), and 312 IU vitamin E (min.). 
$200^{\circ} \mathrm{C}$, column oven temperature of $80^{\circ} \mathrm{C}$ for $3 \mathrm{~min}$ until $240^{\circ} \mathrm{C}\left(20^{\circ} \mathrm{C}\right.$ per minute), carrier gas nitrogen at a constant flow of $3.18 \mathrm{~mL} \mathrm{~min}^{-1}$, detector temperature of $250^{\circ} \mathrm{C}$, and injection volume of $1 \mu \mathrm{L}$.

DM intake was determined by the difference between the offered DM and the DM in the leftovers. Nutrient ingestion was calculated by relating DM with the content of each nutrient in the diet and in the leftovers. Nutrient digestibility (ND) was obtained by the total fecal collection method during the experimental period, using the following formula: $\mathrm{ND}=[$ (ingested DM $\mathrm{x}$ nutrient concentration) (excreted DM x nutrient concentration)]/ (ingested DM $\mathrm{x}$ nutrient concentration).

Data were subjected to the analysis of variance using PROC GLM of the SAS software (SAS Institute Inc., Cary, NC, USA). When statistically different, means were compared by Tukey's test, at $5 \%$ probability. The following model was used: $Y_{i j k}=\mu+p_{i}+A_{j}+t_{k}+\varepsilon_{i j k}$, where $Y_{i j k}$ is the value observed in the portion that received the treatment in replicate block $\mathrm{i}, \mathrm{j}, \mathrm{k} ; \mu$ is the overall average; $p_{i}$ is the effect of blocks $(1,2,3) ; A_{j}$ is the effect of replicates; $t_{k}$ is the effect of treatments $(1$, $2,3,4,5)$; and $\varepsilon_{\mathrm{ijk}}$ is the residual random error.

Table 2. Nutritional composition and in vitro dry matter digestibility of banana (Musa spp.) pseudostem, banana leaf, and Cynodon spp. hay ${ }^{(1)}$.

\begin{tabular}{lccc}
\hline Variable & Pseudostem hay & Leaf hay & Cynodon spp. hay \\
\hline $\mathrm{DM}\left(\mathrm{g} \mathrm{kg}^{-1} \mathrm{NM}\right)$ & 905.4 & 930.7 & 887.4 \\
$\mathrm{MM}\left(\mathrm{g} \mathrm{kg}^{-1} \mathrm{DM}\right)$ & 118.6 & 111.8 & 91.5 \\
$\mathrm{CP}\left(\mathrm{g} \mathrm{kg}^{-1} \mathrm{DM}\right)$ & 34.6 & 122.4 & 99.8 \\
$\mathrm{EE}\left(\mathrm{g} \mathrm{kg}^{-1} \mathrm{DM}\right)$ & 12.1 & 62.1 & 36.4 \\
$\mathrm{NDF}\left(\mathrm{g} \mathrm{kg}^{-1} \mathrm{DM}\right)$ & 499.2 & 599.2 & 663.4 \\
$\mathrm{ADF}\left(\mathrm{g} \mathrm{kg}^{-1} \mathrm{DM}\right)$ & 301.1 & 371.1 & 351.8 \\
$\mathrm{ADIN}\left(\mathrm{g} \mathrm{kg}^{-1} \mathrm{DM}\right)$ & 3.8 & 4.9 & 3.3 \\
$\mathrm{NDIN}\left(\mathrm{g} \mathrm{kg}^{-1} \mathrm{DM}\right)$ & 13.8 & 12.8 & 15.9 \\
NFC $\left(\mathrm{g} \mathrm{kg}^{-1} \mathrm{DM}\right)$ & 335.5 & 104.5 & 108.9 \\
Lignin $\left(\mathrm{g} \mathrm{kg}^{-1} \mathrm{DM}\right)$ & 47.3 & 88.1 & 41.3 \\
TAN $\left(\mathrm{g} \mathrm{kg}^{-1} \mathrm{DM}\right)$ & 0.1 & 7.8 & 3.9 \\
IVDMD & 0.798 & 0.578 & 0.714 \\
\hline
\end{tabular}

(1) DM, dry matter; NM, natural matter; MM, mineral matter; $\mathrm{CP}$, crude protein; EE, ether extract; NDF, neutral detergent fiber; ADF, acid detergent fiber; ADIN, acid detergent insoluble nitrogen; NDIN, neutral detergent insoluble nitrogen; NFC, non-fibrous carbohydrate; TAN, condensed tannins; and IVDMD, in vitro dry matter digestibility.

\section{Results and Discussion}

The NDF content varied among diets with the inclusion of banana crop residues (Table 1), but did not affect DM and organic matter (OM) intake (Table 3). This was probably due to the low variation in the NDF contents in the diets.

Santos et al. (2011) evaluated the DM intake of lambs fed diets containing $15 \%$ protein, $62 \%$ concentrate with different sisal residues, and NDF levels ranging from 31.4 to $37.5 \%$, and did not find differences in DM and OM intake. In the same way, Azevedo et al. (2012), when including different levels of macauba [Acrocomia aculeata (Jacq.) Lodd. ex Mart.] pie in lamb diets, observed that NDF concentrations from 167 to $272 \mathrm{~g} \mathrm{~kg}^{-1}$ did not affect DM and OM intake, which was attributed to the physical processing of the by-product. According to these authors, macauba grinding results in particles with similar size to that of the standard concentrated feed, i.e., corn (Zea mays L.) and soybean [Glycine $\max$ (L.) Merr.] meal, which probably reduced the physical effectiveness of the fibrous fraction.

In the present study, the observed contents for condensed tannins were 7.8, 3.9, and $0.1 \mathrm{~g} \mathrm{~kg}^{-1}$ for banana leaf, Cynodon spp., and banana pseudostem hay, respectively. These values were lower than those reported by Hembade \& Niras (2014), who found 25.8 $\mathrm{g} \mathrm{kg}^{-1}$ for banana leaves and $16.6 \mathrm{~g} \mathrm{~kg}^{-1}$ for banana pseudostem; this difference may be related to the banana species used. Due to their low concentration in the total diet, these compounds did not alter DM and OM intake.

In ruminant diets, besides fibrous fraction and energy content, the presence of phenolic compounds, such as condensed tannins, can negatively affect voluntary intake, by limiting the growth of a number of ruminal microorganisms (Kamra, 2005). Cabral Filho et al. (2013) did not find differences in DM intake when studying three sorghum [Sorghum bicolor (L.) Moench] varieties in diets containing $800 \mathrm{~g} \mathrm{~kg}^{-1}$ concentrate and levels up to $20.4 \mathrm{~g} \mathrm{~kg}^{-1}$ condensed tannins in the DM offered to lambs.

The inclusion of $200 \mathrm{~g} \mathrm{~kg}^{-1}$ banana leaf hay increased EE intake in grams of metabolic body weight $\left(\mathrm{BW}^{0.75}\right)$ per day in relation to the other treatments (Table 3). These results may be explained by the increase in the concentration of this nutrient when banana leaf hay was added to the diet (Table 1). It should be noted 
that the obtained EE content is probably resultant from pigments and not related to the lipid content. According to Van Soest (1994), errors may occur when determining the content of this nutrient, as pigments and waxes present in the leaves end up included in total EE, which could be the case in the present study. A higher EE intake was expected with $400 \mathrm{~g} \mathrm{~kg}^{-1}$ banana leaf; however, this behavior was not observed. There was a lower EE intake in the diet with $400 \mathrm{~g} \mathrm{~kg}^{-1}$ banana leaf than in the one with $200 \mathrm{~g} \mathrm{~kg}^{-1}$ banana leaf, possibly due to diet selection by animals, since the two treatments had similar EE content (Table 1).

The inclusion of banana crop residues did not affect the apparent digestibility of DM and OM in comparison with the treatment with $400 \mathrm{~g} \mathrm{~kg}^{-1}$ Cynodon spp. hay. However, the addition of $400 \mathrm{~g} \mathrm{~kg}^{-1}$ banana pseudostem hay promoted higher digestibility coefficients than $400 \mathrm{~g} \mathrm{~kg}^{-1}$ banana leaf hay (Table 4).

A lower DM and OM digestibility was found for the higher level of banana leaf hay, compared with the same proportion of pseudostem hay, probably due to the higher concentration of lignin $\left(88.1 \mathrm{~g} \mathrm{~kg}^{-1}\right)$ in leaf hay, as DM and OM intake did not differ among the treatments. This result suggests that the addition of banana leaf hay as the only source of forage should be evaluated regarding the cost-benefit relationship and inclusion level in lamb production systems.

The digestibility coefficients of DM and OM found for the highest level of inclusion of banana leaf and pseudostem hay, respectively, are higher than the values of 0.657 and 0.7017 obtained by Rogério et al. (2007) when substituting elephant grass (Pennisetum purpureum Schumach.) in natura with $27 \mathrm{~g} \mathrm{~kg}^{-1}$ sundried pineapple (Ananas comosus L.) residues in diets fed to lambs. However, these authors reported a lignin content of $138.5 \mathrm{~g} \mathrm{~kg}^{-1}$, which is much higher than the highest concentration $\left(34.9 \mathrm{~g} \mathrm{~kg}^{-1}\right)$ in the present study.

The nutritive value of food is determined not only by the concentration of nutrients it has, but also by the amount ingested and digested. The digestibility of DM and $\mathrm{OM}$ of the diet with $400 \mathrm{~g} \mathrm{~kg}^{-1}$ banana pseudostem hay was greater than that of the treatment with banana leaf hay. This can positively interfere with animal performance, as found by Geraseev et al. (2013), who observed that the daily weight gain of growing lambs increased when 200 or $400 \mathrm{~g} \mathrm{~kg}^{-1}$ banana pseudostem hay, compared with banana leaf hay, were added to the diets.

The evaluated diets did not affect the digestibility coefficient of $\mathrm{CP}$, which showed a mean value of 0.686

Table 3. Intake of dry matter (DM), organic matter (OM), crude protein (CP), neutral detergent fiber (NDF), acid detergent fiber (ADF), non-fibrous carbohydrate (NFC), total carbohydrate (CHO), and ether extract (EE) by lambs fed diets containing banana (Musa spp.) crop residues ${ }^{(1)}$.

\begin{tabular}{|c|c|c|c|c|c|c|}
\hline Variable & $\begin{array}{c}400 \mathrm{~g} \mathrm{~kg}^{-1} \text { Cynodon } \\
\text { spp. hay }\end{array}$ & $\begin{array}{c}400 \mathrm{~g} \mathrm{~kg}^{-1} \text { banana } \\
\text { leaf hay }\end{array}$ & $\begin{array}{l}200 \mathrm{~g} \mathrm{~kg}^{-1} \text { banana } \\
\text { leaf hay }\end{array}$ & $\begin{array}{l}400 \mathrm{~g} \mathrm{~kg}^{-1} \text { banana } \\
\text { pseudostem hay }\end{array}$ & $\begin{array}{c}200 \mathrm{~g} \mathrm{~kg}^{-1} \text { banana } \\
\text { pseudostem hay }\end{array}$ & $\begin{array}{l}\text { Coefficient of } \\
\text { variation (\%) }\end{array}$ \\
\hline DM (g per day) & 948.9 & 992.7 & $1,229.8$ & $1,083.4$ & $1,179.3$ & 21.6 \\
\hline $\mathrm{DM}$ (g BW ${ }^{0.75}$ per day) & 66.3 & 68.3 & 89.5 & 78.0 & 81.5 & 18.7 \\
\hline OM (g per day) & 887.1 & 927.3 & $1,138.0$ & 943.5 & $1,104.8$ & 22.0 \\
\hline $\mathrm{OM}$ (g BW ${ }^{0.75}$ per day) & 82.8 & 63.9 & 82.8 & 67.9 & 76.4 & 18.4 \\
\hline CP (g per day) & 158.0 & 162.7 & 203.0 & 188.6 & 201.5 & 22.1 \\
\hline $\mathrm{CP}\left(\mathrm{g} \mathrm{BW}^{0.75}\right.$ per day $)$ & 10.9 & 11.1 & 14.6 & 13.4 & 13.8 & 19.3 \\
\hline NDF (g per day) & 367.6 & 319.93 & 431.0 & 328.5 & 424.5 & 24.4 \\
\hline NDF (g BW ${ }^{0.75}$ per day) & 25.2 & 21.7 & 31.2 & 23.4 & 29.3 & 21.9 \\
\hline ADF (g per day) & 175.0 & 180.6 & 218.0 & 188.7 & 211.6 & 23.5 \\
\hline $\mathrm{ADF}\left(\mathrm{g} \mathrm{BW}^{0.75}\right.$ per day) & 12.0 & 12.3 & 15.8 & 13.3 & 14.6 & 21.1 \\
\hline NFC (g per day) & 322.1 & 371.1 & 433.8 & 426.2 & 397.9 & 22.5 \\
\hline NFC (g BW ${ }^{0.75}$ per day) & 22.5 & 25.9 & 31.8 & 30.9 & 27.4 & 19.4 \\
\hline CHO (g per day) & 725.3 & 691.0 & 864.8 & 754.7 & 822.4 & 21.0 \\
\hline $\mathrm{CHO}$ (g BW $\mathrm{g}^{0.75}$ per day) & 49.6 & 47.6 & 63.0 & 54.4 & 56.8 & 18.5 \\
\hline EE (g per day) & $48.0 \mathrm{ab}$ & $50.1 \mathrm{ab}$ & $66.2 \mathrm{a}$ & $40.0 \mathrm{~b}$ & $52.0 \mathrm{ab}$ & 22.2 \\
\hline $\mathrm{EE}\left(\mathrm{g} \mathrm{BW} \mathrm{W}^{0.75}\right.$ per day) & $3.33 \mathrm{~b}$ & $3.4 \mathrm{~b}$ & $4.7 \mathrm{a}$ & $2.8 \mathrm{~b}$ & $3.59 \mathrm{~b}$ & 18.8 \\
\hline
\end{tabular}

${ }^{(1)}$ Means followed by equal letters do not differ by Tukey's test, at $5 \%$ probability. $\mathrm{BW}^{0.75}$, metabolic body weight. 
(Table 4), i.e., there was no effect of the treatment on the intake of this nutrient (Table 3). This behavior can be attributed to the fixed level of this nutrient (160 $\mathrm{g} \mathrm{kg}^{-1}$ ) and to the ADIN content in the diet.

The digestibility of forage is mainly related to the composition of the cellular wall and to the access of ruminal microorganisms to the plant tissues. Therefore, the presence of lignin in this fraction may interfere with the use of fibrous carbohydrates (Moore \& Jung, 2001). In the present study, the inclusion of $400 \mathrm{~g} \mathrm{~kg}^{-1}$ banana leaf hay reduced NDF digestibility in relation to the treatments containing Cynodon spp. hay or banana pseudostem hay (Table 4). These results may be explained by the higher percentage of ADF and higher content of lignin (Table 1) in that treatment. This information is based on the lower IVDMD (578 $\mathrm{g} \mathrm{kg}^{-1}$ ) and on the lignin content of this forage (Table 2). Furthermore, the IVDMDs of Cynodon spp. and pseudostem hay were similar to and higher than, respectively, that obtained for leaf hay. Therefore, the fine components of these diets seem unavailable to the ruminal flora due to the barrier of lignin polymers.

The inclusion of $400 \mathrm{~g} \mathrm{~kg}^{-1}$ banana pseudostem hay resulted in an increase in ADF digestibility in relation to the treatment with $400 \mathrm{~g} \mathrm{~kg}^{-1}$ banana leaf hay. The levels of inclusion and the type of residue used, however, did not affect the digestibility of this fraction when compared with Cynodon spp. hay (Table 4). ADF showed a similar behavior to that of lignin content, probably because it is composed by cellulose and lignin; however, the higher the lignin content, the lower ADF digestibility.
Similar results were obtained by Rogério et al. (2007) when evaluating the digestibility of fibrous components by lambs (weighing $32 \mathrm{~kg}$ ) fed diets containing up to $270 \mathrm{~g} \mathrm{~kg}^{-1}$ of dried pineapple residues in substitution of elephant grass in natura. When the by-product was included, there was lower ADF digestibility and a discrete increase in lignin content (130 to $139 \mathrm{~g} \mathrm{~kg}^{-1}$ ).

Despite the higher non-fibrous carbohydrate concentration in the diets containing banana pseudostem hay (Table 1), there was no effect on the intake of this nutrient, which can justify the similarity observed for the digestibility of this fraction. There was also no effect of the diet on the concentration of SCFA (Table 5). However, the inclusion of banana leaf hay increased the acetate:propionate proportion, when compared with the addition of $400 \mathrm{~g} \mathrm{~kg}^{-1}$ banana pseudostem hay.

According to Valadares Filho \& Pina (2011), the acetate:propionate:butyrate molar ratio can range from 75:15:10 to 40:40:20 for diets with higher fibrous carbohydrate concentration and lower proportion of non-fibrous carbohydrates, respectively. In the present study, the obtained values remained within this range, indicating that the prevailing inclusion of banana crop residues does not alter significantly the population of bacteria in the rumen.

Most of the energy required by ruminants can be supplied by SCFA and is directly related to the conditions of fermentation and to the control of the ruminal environment; diets with greater digestibility normally result in higher SCFA concentration in the rumen (Gilaverte et al., 2011). In the present study,

Table 4. Coefficients of digestibility of dry matter (DM), organic matter (OM), crude protein (CP), neutral detergent fiber (NDF), acid detergent fiber (ADF), non-fibrous carbohydrate (NFC), and total carbohydrate (CHO) for lambs fed diets containing banana (Musa spp.) crop residues ${ }^{(1)}$.

\begin{tabular}{|c|c|c|c|c|c|c|}
\hline Variable & $\begin{array}{c}400 \mathrm{~g} \mathrm{~kg}^{-1} \text { Cynodon } \\
\text { spp. hay }\end{array}$ & $\begin{array}{c}400 \mathrm{~g} \mathrm{~kg}^{-1} \text { banana } \\
\text { leaf hay }\end{array}$ & $\begin{array}{c}200 \mathrm{~g} \mathrm{~kg}^{-1} \text { banana } \\
\text { leaf hay }\end{array}$ & $\begin{array}{l}400 \mathrm{~g} \mathrm{~kg}^{-1} \text { banana } \\
\text { pseudostem hay }\end{array}$ & $\begin{array}{l}200 \mathrm{~g} \mathrm{~kg}^{-1} \text { banana } \\
\text { pseudostem hay }\end{array}$ & $\begin{array}{l}\text { Coefficient of } \\
\text { variation }(\%)\end{array}$ \\
\hline DM & $0.711 \mathrm{ab}$ & $0.679 \mathrm{~b}$ & $0.717 \mathrm{ab}$ & $0.762 \mathrm{a}$ & $0.741 \mathrm{ab}$ & 5.5 \\
\hline $\mathrm{OM}$ & $0.721 \mathrm{ab}$ & $0.689 \mathrm{~b}$ & $0.728 \mathrm{ab}$ & $0.778 \mathrm{a}$ & $0.757 \mathrm{ab}$ & 5.4 \\
\hline $\mathrm{CP}$ & 0.699 & 0.706 & 0.672 & 0.677 & 0.675 & 8.4 \\
\hline $\mathrm{NDF}$ & $0.606 a$ & $0.459 \mathrm{~b}$ & $0.526 \mathrm{ab}$ & $0.599 a$ & $0.587 \mathrm{a}$ & 10.4 \\
\hline $\mathrm{ADF}$ & $0.482 \mathrm{ab}$ & $0.373 b$ & $0.433 \mathrm{ab}$ & $0.533 a$ & $0.502 \mathrm{ab}$ & 17.0 \\
\hline $\mathrm{NFC}$ & 0.882 & 0.904 & 0.890 & 0.939 & 0.913 & 5.5 \\
\hline $\mathrm{CHO}$ & $0.730 \mathrm{ab}$ & $0.700 \mathrm{~b}$ & $0.730 \mathrm{ab}$ & $0.784 a$ & $0.748 \mathrm{ab}$ & 6.1 \\
\hline
\end{tabular}

${ }^{(1)}$ Means followed by equal letters do not differ by Tukey's test, at $5 \%$ probability. 
Table 5. Mean concentration of $\mathrm{pH}$ values of short-chain fatty acids (SCFA) and the acetate:propionate (A:P) ratio of the ruminal liquid of lambs fed diets containing banana (Musa spp.) crop residues ${ }^{(1)}$.

\begin{tabular}{|c|c|c|c|c|c|c|}
\hline Variable & $\begin{array}{c}400 \mathrm{~g} \mathrm{~kg}^{-1} \\
\text { Cynodon spp. hay }\end{array}$ & $\begin{array}{c}400 \mathrm{~g} \mathrm{~kg}^{-1} \\
\text { banana leaf hay }\end{array}$ & $\begin{array}{c}200 \mathrm{~g} \mathrm{~kg}^{-1} \\
\text { banana leaf hay }\end{array}$ & $\begin{array}{l}400 \mathrm{~g} \mathrm{~kg}^{-1} \text { banana } \\
\text { pseudostem hay }\end{array}$ & $\begin{array}{l}200 \mathrm{~g} \mathrm{~kg}^{-1} \text { banana } \\
\text { pseudostem hay }\end{array}$ & $\begin{array}{l}\text { Coefficient of } \\
\text { variation (\%) }\end{array}$ \\
\hline $\mathrm{pH}$ & 6.94 & 7.24 & 7.27 & 6.90 & 7.01 & 10.1 \\
\hline & \multicolumn{6}{|c|}{ SCFA concentration $\left(\mathrm{mM} \mathrm{L}^{-1}\right)$} \\
\hline Acetate & 34.12 & 29.01 & 36.08 & 31.45 & 40.4 & 28.9 \\
\hline Propionate & 10.9 & 8.2 & 10.1 & 11.6 & 13.0 & 30.6 \\
\hline Butyrate & 5.7 & 3.8 & 5.6 & 5.8 & 6.6 & 30.3 \\
\hline Isobutyrate & 0.8 & 0.8 & 0.9 & 0.6 & 1.1 & 25.5 \\
\hline Isovalerate & 1.4 & 1.4 & 1.6 & 1.0 & 1.7 & 27.2 \\
\hline Valerate & 0.5 & 0.4 & 0.5 & 0.4 & 0.7 & 33.3 \\
\hline A:P & $3.2 \mathrm{ab}$ & $3.5 \mathrm{a}$ & $3.5 \mathrm{a}$ & $2.8 \mathrm{~b}$ & $3.1 \mathrm{ab}$ & 9.0 \\
\hline \multirow[t]{2}{*}{ Total SCFA } & 53.4 & 43.6 & 54.7 & 50.8 & 63.5 & 26.7 \\
\hline & \multicolumn{6}{|c|}{ Molar proportion of SCFA } \\
\hline Acetate & 0.638 & 0.665 & 0.658 & 0.618 & 0.636 & 3.4 \\
\hline Propionate & $0.204 a b$ & $0.188 b$ & $0.184 b$ & $0.228 \mathrm{a}$ & $0.204 a b$ & 9.7 \\
\hline Butyrate & $0.106 a b$ & $0.087 \mathrm{~b}$ & $0.102 \mathrm{ab}$ & $0.114 . a$ & $0.103 \mathrm{ab}$ & 10.9 \\
\hline
\end{tabular}

${ }^{(1)}$ Means followed by equal letters do not differ by Tukey's test, at $5 \%$ probability.

the highest digestibility coefficient of nutrients observed for the inclusion of $400 \mathrm{~g} \mathrm{~kg}^{-1}$ pseudostem hay, compared with that of $400 \mathrm{~g} \mathrm{~kg}^{-1}$ leaf hay, did not affect the total production of SCFA, which was similar in all tested diets.

The inclusion of banana crop residues did not affect the molar proportion of acetate in the diets, which showed a mean of 0.643 . This may have occurred due to the active degradation of the microbial population, considering that ruminal $\mathrm{pH}$ was maintained close to neutral in all treatments (Table 5). However, it is important to highlight that the average $\mathrm{pH}$ was $7.0 \pm 0.15$, which may have been affected by the collection time (12 hours post-fasting) of the ruminal liquid in the present study.

The addition of $400 \mathrm{~g} \mathrm{~kg}^{-1}$ banana pseudostem hay increased the proportion of propionate and butyrate in the ruminal fluid in comparison with the diet containing $400 \mathrm{~g} \mathrm{~kg}^{-1}$ leaf hay. The higher non-fibrous carbohydrate concentration in the diet with banana pseudostem hay than with leaf hay (Table 1) - due to the high ruminal degradation rate and better fermentative quality (Oliveira et al., 2014) - favors the production of propionate, which explains these results.

The lower molar proportion of propionate found in the treatment containing banana leaf hay, compared with banana pseudostem hay, may partially explain the acetate:propionate relationship observed for these treatments, considering that no difference was found for acetate production among the evaluated diets. These results are in alignment with those of previous studies (Amarnath \& Balakrishnan, 2007), which showed higher propionate concentrations and lower acetate:propionate proportions in diets containing up to $400 \mathrm{~g} \mathrm{~kg}^{-1}$ concentrate and up to $600 \mathrm{~g} \mathrm{~kg}^{-1}$ banana pseudostem, in comparison with similar amounts of banana leaf. The production of propionic acid is more energetically efficient and, theoretically, reduces energy loss as methane, normally associated with acetate production (Rivera et al., 2010). Therefore, it is possible to hypothesize that when reducing the molar proportion of acetate:propionate, the inclusion of banana pseudostem hay will enable an increase in the glycogenic potential of the diets, enhance the efficiency of the energy metabolism, and decrease the energy lost as methane.

\section{Conclusions}

1. Both banana (Musa spp.) pseudostem and leaf hay can replace Cynodon spp. hay in lamb diets without changing intake, nutrient digestibility, and ruminal concentration of short-chain fatty acids.

2. The addition of banana pseudostem hay as the only source of forage in lamb diets results in greater dry matter and fiber fraction digestibility than banana leaf hay. 


\section{Acknowledgments}

To Fundação de Amparo à Pesquisa do Estado de Minas Gerais (Fapemig), for financial support.

\section{References}

AMARNATH, R.; BALAKRISHNAN, V. Assessment on the replacement value of the banana (Musa paradisiaca) plant byproducts for their fodder potential in complete diet of ruminants. International Journal of Agricultural Research, v.2, p.696703, 2007. DOI: 10.3923/ijar.2007.696.703.

AZEVEDO, R.A. de; RUFINO, L.M. de A.; SANTOS, A.C.R. dos; SILVA, L.P. da; BONFÁ, H.C.; DUARTE, E.R.; GERASEEV, L.C. Desempenho de cordeiros alimentados com inclusão de torta de macaúba na dieta. Pesquisa Agropecuária Brasileira, v.47, p.1663-1668, 2012. DOI: 10.1590/S0100204X2012001100014.

BARRETO, H.F.M.; LIMA, P.O.; SOUZA, C.M.S.; MOURA, A.A.C.; ALENCAR, R.D.; CHAGAS, F.P.T. Uso de coprodutos de frutas tropicais na alimentação de ovinos no semiárido do Brasil. Archivos de Zootecnia, v.63, p.117-131, 2014. DOI: 10.21071/az.v63i241.594.

BARROS, M.C.C.; MARQUES, J. de A.; SILVA, F.F. da; SILVA, R.R.; GUIMARÃES, G.S.; SILVA, L.L. da; ARAUJO, F.L. de. Glicerina bruta na dieta de ovinos confinados: consumo, digestibilidade, desempenho, medidas morfométricas da carcaça e características da carne. Semina: Ciências Agrárias, v.36, p.453-466, 2015. DOI: 10.5433/1679-0359.2015v36n1p453.

BRAGA SOBRINHO, R. Produção integrada de Anonáceas no Brasil. Revista Brasileira de Fruticultura, v.36, p.102-107, 2014. DOI: $10.1590 /$ S0100-29452014000500012.

CABRAL FILHO, S.L.S.; ABDALLA, A.L.; BUENO, I.C.S.; GOBBO, S.P.; OLIVEIRA, A.A.M. Effect of sorghum tannins in sheep fed with high-concentrate diets. Arquivo Brasileiro de Medicina Veterinária e Zootecnia, v.65, p.1759-1766, 2013. DOI: $10.1590 / \mathrm{S} 0102-09352013000600025$.

DETMANN, E.; SOUZA, M.A. de; VALADARES FILHO, S. de C.; QUEIROZ, A.C. de; BERCHIELLI, T.T.; SALIBA, E. de O.S.; CABRAL, L. da S.; PINA, D. do S.; LADEIRA, M.M.; AZEVEDO, J.A.G. Métodos para análise de alimentos. Visconde do Rio Branco: Suprema, 2012. 193p.

GERASEEV, L.C.; MOREIRA, S. de J.M.; ALVES, D.D.; AGUIAR, A.C.R.; MONÇÃO, F.P.; DOS SANTOS, A.C.R.; SANTANA, C.J.L.; VIEGAS, C.R. Viabilidade econômica da utilização dos resíduos da bananicultura na alimentação de cordeiros confinados. Revista Brasileira de Saúde e Produção Animal, v.14, p.734-744, 2013. DOI: 10.1590/S151999402013000400017.

GILAVERTE, S.; SUSIN, I.; PIRES, A.V.; FERREIRA, E.M.; MENDES, C.Q.; GENTIL, R.S.; BIEHL, M.V.; RODRIGUES, G.H. Digestibilidade da dieta, parâmetros ruminais e desempenho de ovinos Santa Inês alimentados com polpa cítrica peletizada e resíduo úmido de cervejaria. Revista Brasileira de Zootecnia, v.40, p.639-647, 2011. DOI: 10.1590/S1516-35982011000300024.

HEMBADE, A.S.; NIRAS, V.V. Evaluation of some toxic principles of banana (Musa sps.). International Journal of Green and Herbal Chemistry, v.3, p.1726-1729, 2014.

HIERMANN, A.; KARTNIG, T.H.; AZZAM, S. Ein Beitrag zur quantitativen Bestimmung der Procyanidine in Crataegus. Scientia Pharm, v.54, p.331-337, 1986.

HOLDEN, L.A. Comparison of methods of in vitro dry matter digestibility for ten feeds. Journal of Dairy Science, v.82, p.1791-1794, 1999. DOI: 10.3168/jds.S0022-0302(99)75409-3.

KAMRA, D.N. Rumen microbial ecosystem. Current Science, v.89, p.124-134, 2005.

MOORE, K.J.; JUNG, H.-J.G. Lignin and fiber digestion. Journal of Range Management, v.54, p.420-430, 2001. DOI: $10.2307 / 4003113$.

NOCEK, J.E.; HART, S.P.; POLAN, C.E. Rumen ammonia concentrations as influenced by storage time, freezing and thawing, acid preservative, and method of ammonia determination. Journal of Dairy Science, v.70, p.601-607, 1987. DOI: $10.3168 /$ jds.S0022-0302(87)80047-4.

NUTRIENT requirements of small ruminants: sheep, goats, cervids, and new world camelids. Washington: National Academy Press, 2007. DOI: 10.17226/11654.

OLIVEIRA, L.N.; CABRAL FILHO, S.L.S.; GERASEEV, L.C.; DUARTE, E.R.; ABDALLA, A.L. Chemical composition, degradability and methane emission potential of banana crop residues for ruminants. Tropical and Subtropical Agroecosystems, v.17, p.197-206, 2014.

RAINERI, C.; SANTOS, F.F. dos; GAMEIRO, A.H. Ovinocultura de corte no Brasil: balanço de 2013 e perspectivas para 2014. Revista de Educação Continuada em Medicina Veterinária e Zootecnia do CRMV-SP, v.12, p.12-17, 2014.

RIVERA, A.R.; BERCHIELLI, T.T.; MESSANA, J.D.; VELASQUEZ, P.T.; FRANCO, A.V.M.; FERNANDES, L.B. Fermentação ruminal e produção de metano em bovinos alimentados com feno de capim-tifton 85 e concentrado com aditivos. Revista Brasileira de Zootecnia, v.39, p.617-624, 2010. DOI: 10.1590/S1516-35982010000300022.

ROGÉRIO, M.C.P.; BORGES, I.; NEIVA, J.N.M.; RODRIGUEZ, N.M.; PIMENTEL, J.C.M.; MARTINS, G.A.; RIBEIRO, T.P.; COSTA, J.B.; SANTOS, S.F.; CARVALHO, F.C. Valor nutritivo do resíduo da indústria processadora de abacaxi (Ananas comosus L.) em dietas para ovinos. 1. Consumo, digestibilidade aparente e balanços energético e nitrogenado. Arquivo Brasileiro de Medicina Veterinária e Zootecnia, v.59, p.773-781, 2007. DOI: 10.1590/S0102-09352007000300032.

SANTOS, R.D.; PEREIRA, L.G.R.; NEVES, A.L.A.; BRANDÃO, L.G.N.; ARAÚJO, G.G.L.; ARAGÃO, A.S.L.; BRANDÃO, W.N.; SOUZA, R.A.; OLIVEIRA, G.F. Consumo e desempenho produtivo de ovinos alimentados com dietas que continham coprodutos do desfibramento do sisal. Arquivo 
Brasileiro de Medicina Veterinária e Zootecnia, v.63, p.15021510, 2011. DOI: 10.1590/S0102-09352011000600030.

TABELEÃO, V.C.; DEL PINO, F.A.B.; GOULART, M.A.; SCHWEGLER, E.; MOURA, S.V.; CORRÊA, M.N. Influência da monensina e levedura sobre parâmetros ruminais e metabólicos em cordeiros semiconfinados. Acta Scientiarum. Animal Sciences, v.30, p.181-186, 2008. DOI: 10.4025/actascianimsci. v30i2.4687.

TILLEY, J.M.A.; TERRY, R.A. A two-stage technique for the in vitro digestion of forage crops. Grass and Forage Science, v.18, p.104-111, 1963. DOI: 10.1111/j.1365-2494.1963.tb00335.x.
VALADARES FILHO, S.C.; PINA, D.S. Fermentação ruminal. In: BERCHIELLI, T.T.; PIRES, A.V.; OLIVEIRA S.G. de (Ed.). Nutrição de ruminantes. 2.ed. Jaboticabal: Funep, 2011. p.161-189.

VAN SOEST, P.J. Nutritional ecology of the ruminant. $2^{\text {nd }}$ ed. Ithaca: Cornell University Press, 1994. 476p.

VAN SOEST, P.J. Symposium on factors influencing the voluntary intake of herbage by ruminants: voluntary intake in relation to chemical composition and digestibility. Journal of Animal Science, v.24, p.834-843, 1965. DOI: $10.2527 /$ jas1965.243834x.

Received on March 2, 2017 and accepted on June 21, 2017 